2 Impacts of proteins on dissolution and sulfidation of silver nanowires in

3 aquatic environment: Importance of surface charges

4 Yinqing Zhang, Jinliang Xu, Yi Yang, Binbin Sun, Kunkun Wang, Lingyan Zhu*

5

6 Key Laboratory of Pollution Processes and Environmental Criteria (Ministry of Education), Tianjin

7 Key Laboratory of Environmental Remediation and Pollution Control, College of Environmental

8 Science and Engineering, Nankai University, Tianjin 300350, P. R. China

9

10

11

12

13

14 Summary:

15 Number of Pages: 16

16 Page S2-S5: Additional Experimental Details

17 Page S6-S9: Table S1-Table S4

18 Page S10-S15: Figure S1-Figure S6

19 Page S16: Reference 


\section{Synthesis and characterization of AgNWs.}

AgNWs were synthesized with slight modifications to the solvothermal method. ${ }^{1}$ Briefly, 32

$23 \mathrm{mg} \mathrm{NaCl}$ and $3.1 \mathrm{~g}$ PVP were dissolved in $28 \mathrm{~mL}$ of ethylene glycol (EG). $0.5 \mathrm{~g} \mathrm{AgNO}$ was

24 dissolved in $42 \mathrm{~mL}$ of $\mathrm{EG}$ in dark. Then the mixed solution of $\mathrm{PVP} / \mathrm{NaCl} / \mathrm{EG}$ was injected to the

$25 \mathrm{AgNO}_{3} / \mathrm{EG}$ solution drop by drop under vigorous stirring. The mixture solution was kept at $120^{\circ} \mathrm{C}$

26 for $10 \mathrm{~min}$, and was transferred to a polytetrafluoroethylene autoclave and kept at $160{ }^{\circ} \mathrm{C}$ for $7 \mathrm{~h}$.

27 Finally, the autoclave was cooled to room temperature. The AgNWs products were washed with

28 ethanol and then ultrapure water by centrifugal ultrafiltration (Amicon Ultra-15 30kD, Millipore,

$29 \mathrm{MA})$ at $2050 \mathrm{~g}$ for $20 \mathrm{~min}$. The washing process was repeated twice. The stock suspension of

30 AgNWs was stored at $4{ }^{\circ} \mathrm{C}$ in dark for later use.

31 
32 The equipment in the AgNWs dissolution and sulfidation experiments.

33 Both the dissolution and sulfidation experiments of AgNWs were performed in a custom-built

34 photochemical reactor. A series of test tubes containing the reaction mixture was were rotated at

$3510 \mathrm{rpm}$ facing an $800 \mathrm{~W}$ Xenon lamp. The test tubes in the AgNWs oxidative dissolution and

36 sulfidation experiments were made of quartz glass, which is transparent for light with wavelengths

37 above around $200 \mathrm{~nm}$. The Xenon lamp equipped with a $280 \mathrm{~nm}$ filter was used to simulate the

38 sunlight irradiation. The light intensity was $216 \mathrm{~mW} / \mathrm{cm}^{2}$.

39 
Measurement of time-resolved sulfide concentration.

To avoid the loss of sulfide via evaporation as violate $\mathrm{H}_{2} \mathrm{~S}$ and $\mathrm{HS}^{-}$, a stock solution of $\mathrm{Na}_{2} \mathrm{~S}$

42 was freshly prepared right before the tests. At predetermined times, soluble sulfide $\left(\mathrm{H}_{2} \mathrm{~S}(\mathrm{aq}) / \mathrm{HS}^{-}\right.$

$43 \quad / \mathrm{S}^{2-}$ ) in the reaction system was measured using a modified methylene blue spectrophotometric

44 method. In a typical experiment, predetermined volumes of protein, AgNWs suspension and $\mathrm{Na}_{2} \mathrm{~S}$

45 solution were added sequentially to ultrapure water to obtain $10 \mathrm{~mL}$ of reaction suspension in each

46 quartz test tube with screw cap. A series of test tubes containing the reaction mixture were rotated

47 at $10 \mathrm{rpm}$ facing an $800 \mathrm{~W}$ Xe lamp to simulate sunlight irradiation. At each predetermined reaction

48 time, one tube was sacrificed for total sulfide measurement. The solution was separated from the

49 colloids by centrifugal ultrafiltration, and an aliquot of $2.0 \mathrm{~mL}$ of the filtrate was added in a $50 \mathrm{~mL}$

50 test tube which contained $10.0 \mathrm{~mL}$ of zinc acetate $(5.0 \mathrm{wt} \%)$ and sodium acetate $(1.3 \mathrm{wt} \%)$ solution

51 (the mixture was solution A). The color development reagent (solution B) was prepared by mixing

$52200 \mathrm{~mL}$ of $1.0 \mathrm{wt} \% \mathrm{~N}, N$-dimethyl-p-phenylenediamine monohydrochloride with $200 \mathrm{~mL}$ of

53 concentrated sulfuric acid, and then the mixture was cooled down and diluted to $1000 \mathrm{~mL}$ in a dark

54 brown bottle with distilled water. $5.0 \mathrm{~mL}$ of solution $\mathrm{B}$ and $0.5 \mathrm{~mL}$ of $10.0 \mathrm{wt} \%$ ammonium iron

55 (III) sulfate solution were mixed with solution A immediately. After sterilizing for 10 min, the

56 mixture was diluted to $50 \mathrm{~mL}$ with distilled water. The absorbance of the testing solution at 665

57 nm was measured on a Hitachi U3900H UV-vis spectrophotometer (Japan). The total sulfide

58 concentration was calculated according to a linear calibration curve constructed from freshly $\mathrm{Na}_{2} \mathrm{~S}$

59 standard solutions. 
For quantitative analysis of quenching processes, quenching rate constants $k_{\mathrm{q}}$ were obtained

62 by using Stern-Volmer equation (Eq. 1): ${ }^{2}$

$$
\mathrm{F}_{0} / \mathrm{F}=1+k_{\mathrm{q}} \tau_{0}[Q]=1+K_{\mathrm{SV}}[Q]
$$

64 where $F_{0}$ and $F$ represent the fluorescence intensities in the absence and presence of quencher

65 (AgNWs), respectively; $k_{q}$ is biomolecular quenching rate constant; $K_{S V}$ is the Stern-Volmer

66 constant, $\tau_{0}$ is average lifetime of the molecular without quencher and $[Q]$ is the concentration of

67 the quencher. The fluorescence lifetime of a biomolecular was ordered as $1 \times 10^{-8} \mathrm{~s}^{3} k_{\mathrm{q}}$ was used

68 to estimate the quenching mechanism, compared with the maximum scatter quenching constant in

69 case of the dynamic quenching $\left(2 \times 10^{10} \mathrm{~L} / \mathrm{mol} \cdot \mathrm{s}\right) .{ }^{4}$ The calculated values of $k_{\mathrm{q}}$ in Table 2 were all

70 in the order of $10^{12} \mathrm{~L} / \mathrm{mol} \cdot \mathrm{s}$ and much higher than the maximal rate constant, indicating that the

71 static quenching had happened between AgNWs and proteins rather than a dynamic mechnism. ${ }^{5}$

72 With a static quenching process, the interaction between AgNWs and proteins can be analyzed with

73 the following Eq. (2):

$$
\log \left[\left(\mathrm{F}_{0}-\mathrm{F}\right) / \mathrm{F}\right]=\log K_{\mathrm{F}}+\mathrm{n} \log [\mathrm{Q}]
$$

75 The linear regression of a plot of $\log \left[\left(\mathrm{F}_{0}-\mathrm{F}\right) / \mathrm{F}\right]$ versus $\log [\mathrm{Q}]$ is used to determine the number of

76 binding sites $\mathrm{n}$ equal to slope and the binding constant $K_{\mathrm{F}}$ equal to intercept on $\mathrm{Y}$-axis. $K_{\mathrm{F}}$ denoted

77 the binding capacity of fluorophore and quencher, which increased with the increasing binding 78 affinity. $^{6}$ 
Table S1. Major characteristics of the three proteins applied in this study.

80

\begin{tabular}{lccc}
\hline \multicolumn{1}{c}{ Property } & OVA & BSA & LYZ \\
\hline Molecular weight (kDa) & 44.5 & 66.4 & 14.7 \\
Isoelectric point & 4.5 & 4.7 & 10.7 \\
Amino acids & 385 & 583 & 129 \\
Sulfhydryl group & 4 & 1 & 0 \\
Disulfide bond & 1 & 17 & 4 \\
Tryptophan residues & 3 & 2 & 6 \\
\hline
\end{tabular}


82 Table S2. The concentrations of the three proteins and AgNWs in mass/volume units.

Molar concentration Concentration in mass/volume units

AgNWs

$10 \mu \mathrm{M}$

$1.08 \mathrm{mg} / \mathrm{L}$ of $\mathrm{Ag}$

OVA

$15 \mathrm{nM}$

$0.668 \mathrm{mg} / \mathrm{L}$

$75 \mathrm{nM}$

$3.34 \mathrm{mg} / \mathrm{L}$

$150 \mathrm{nM}$

$6.68 \mathrm{mg} / \mathrm{L}$

$300 \mathrm{nM}$

$13.4 \mathrm{mg} / \mathrm{L}$

BSA

$15 \mathrm{nM}$

$0.996 \mathrm{mg} / \mathrm{L}$

$75 \mathrm{nM}$

$4.98 \mathrm{mg} / \mathrm{L}$

$150 \mathrm{nM}$

$9.96 \mathrm{mg} / \mathrm{L}$

$300 \mathrm{nM}$

$19.9 \mathrm{mg} / \mathrm{L}$

LYZ

$15 \mathrm{nM}$

$0.221 \mathrm{mg} / \mathrm{L}$

$75 \mathrm{nM}$

$1.10 \mathrm{mg} / \mathrm{L}$

$150 \mathrm{nM}$

$2.21 \mathrm{mg} / \mathrm{L}$

$300 \mathrm{nM}$

$4.41 \mathrm{mg} / \mathrm{L}$

83 


\begin{tabular}{llll}
\hline & OVA & BSA & LYZ \\
\hline $0 \mu \mathrm{M}$ AgNWs & 333.1 & 336.3 & 339.5 \\
$10 \mu \mathrm{M}$ AgNWs & 332.8 & 336.0 & 339.0 \\
$20 \mu \mathrm{M} \mathrm{AgNWs}$ & 332.5 & 335.6 & 338.2 \\
$40 \mu \mathrm{M}$ AgNWs & 332.0 & 335.0 & 337.3 \\
$60 \mu \mathrm{M}$ AgNWs & 331.2 & 334.2 & 335.9 \\
$80 \mu \mathrm{M}$ AgNWs & 330.4 & 333.5 & 332.7 \\
$100 \mu \mathrm{M}$ AgNWs & 329.7 & 332.8 & 331.6 \\
\hline
\end{tabular}

85 
Table S4. Quenching rate constants $k_{\mathrm{q}}$, binding constants $K_{\mathrm{F}}$ and number of binding sites $\mathrm{n}$ between AgNWs and proteins.

\begin{tabular}{lcccc}
\hline & $k_{q}$ & $K_{\mathrm{F}}$ & & \\
& $\left(\times 10^{12} \mathrm{~L} / \mathrm{mol} \cdot \mathrm{s}\right)$ & $\left(\times 10^{4} \mathrm{~L} / \mathrm{mol}\right)$ & $\mathrm{n}$ & $\mathrm{R}^{2}$ \\
\hline $\begin{array}{c}\text { AgNWs in } \\
\text { OVA }\end{array}$ & 1.56 & 0.94 & 1.07 & 0.9834 \\
$\begin{array}{c}\text { AgNWs in } \\
\text { BSA } \\
\text { AgNWs in } \\
\text { LYZ }\end{array}$ & 1.08 & 1.23 & 1.11 & 0.9542 \\
\hline
\end{tabular}

88

$\mathrm{R}^{2}$ is the correlation coefficient. 


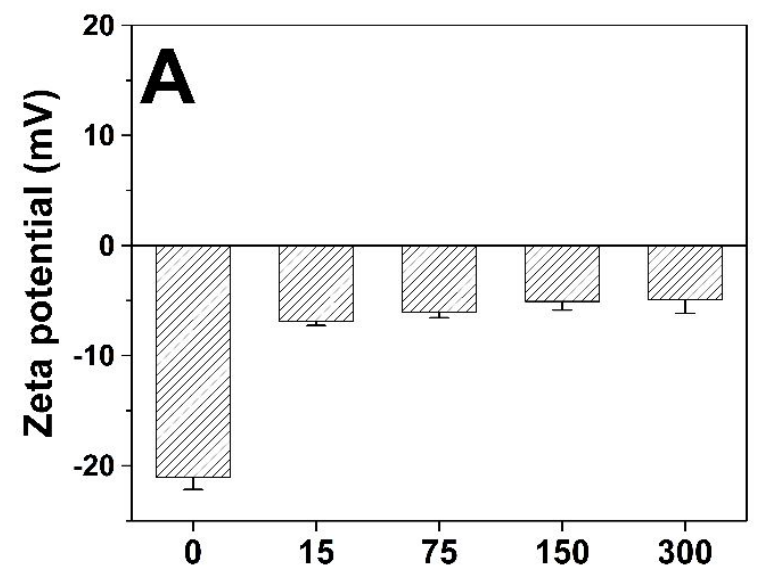

90

Protein concentration (nM)
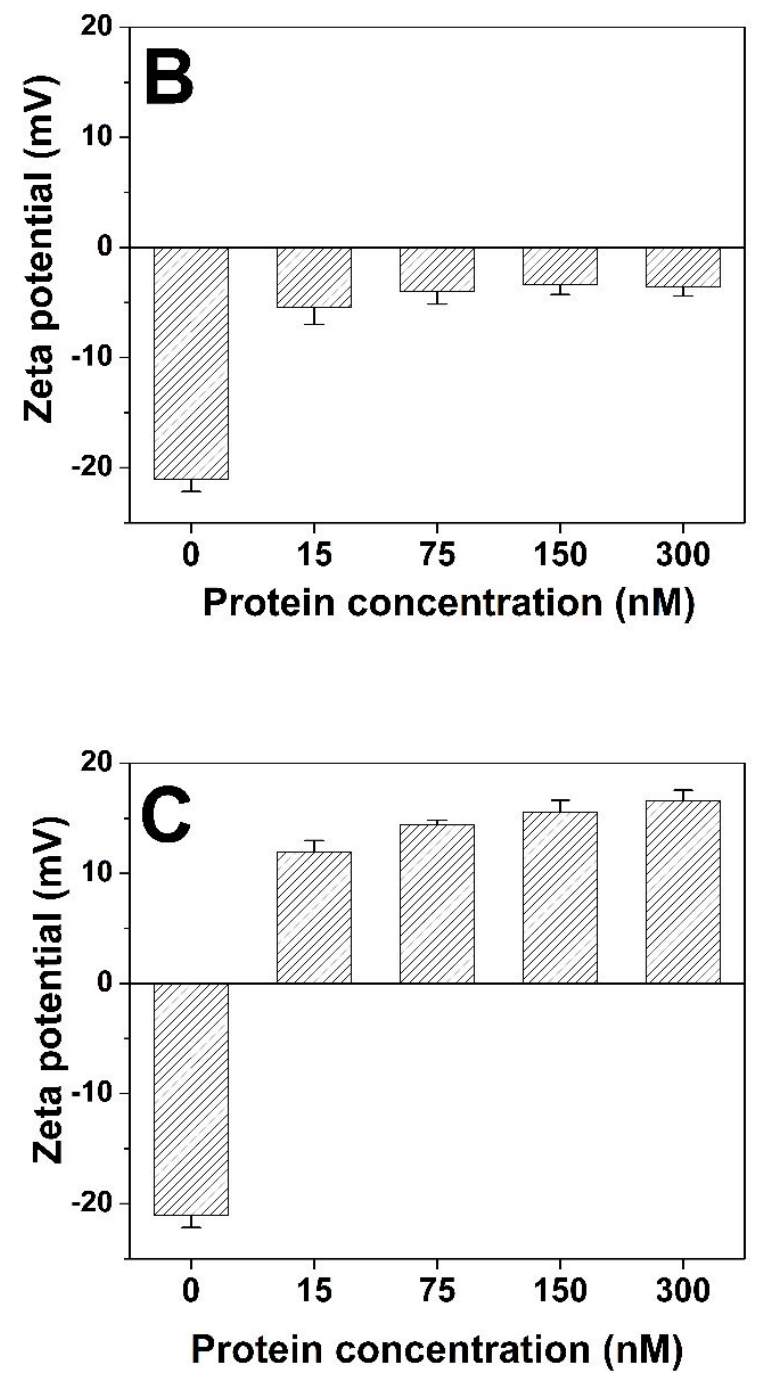

Protein concentration (nM)

93 Figure S1 Zeta potential of AgNWs dispersed in different media at different concentrations. (A) 

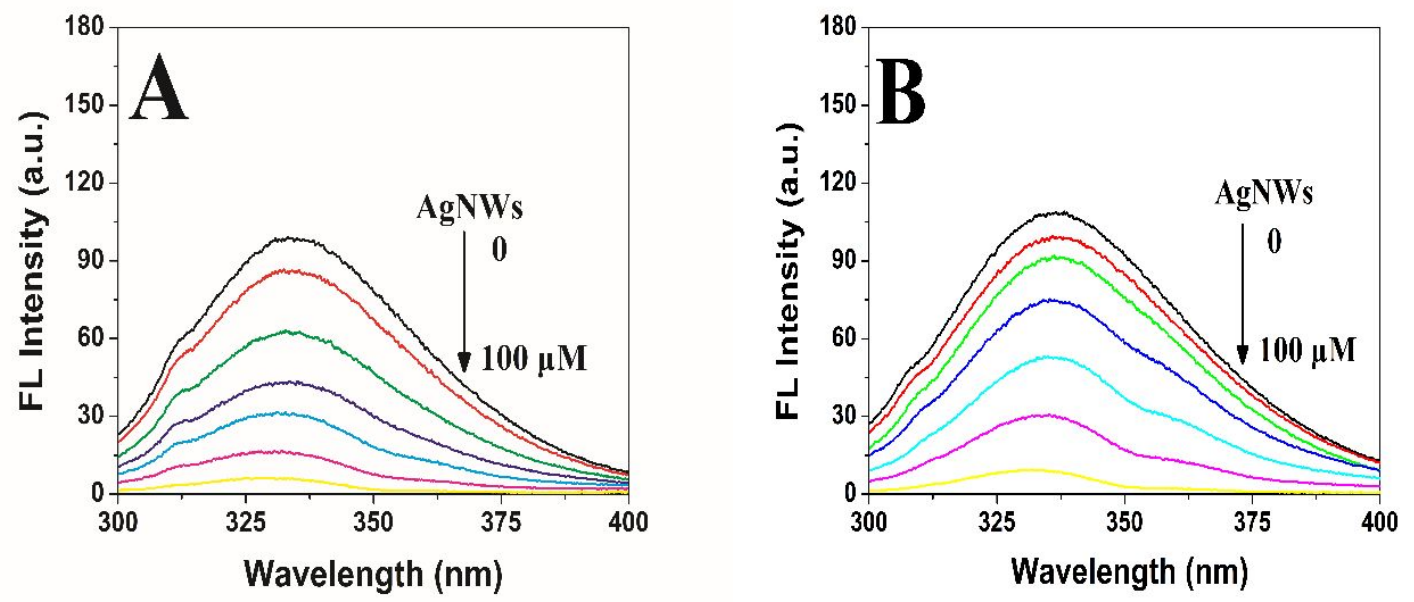

95
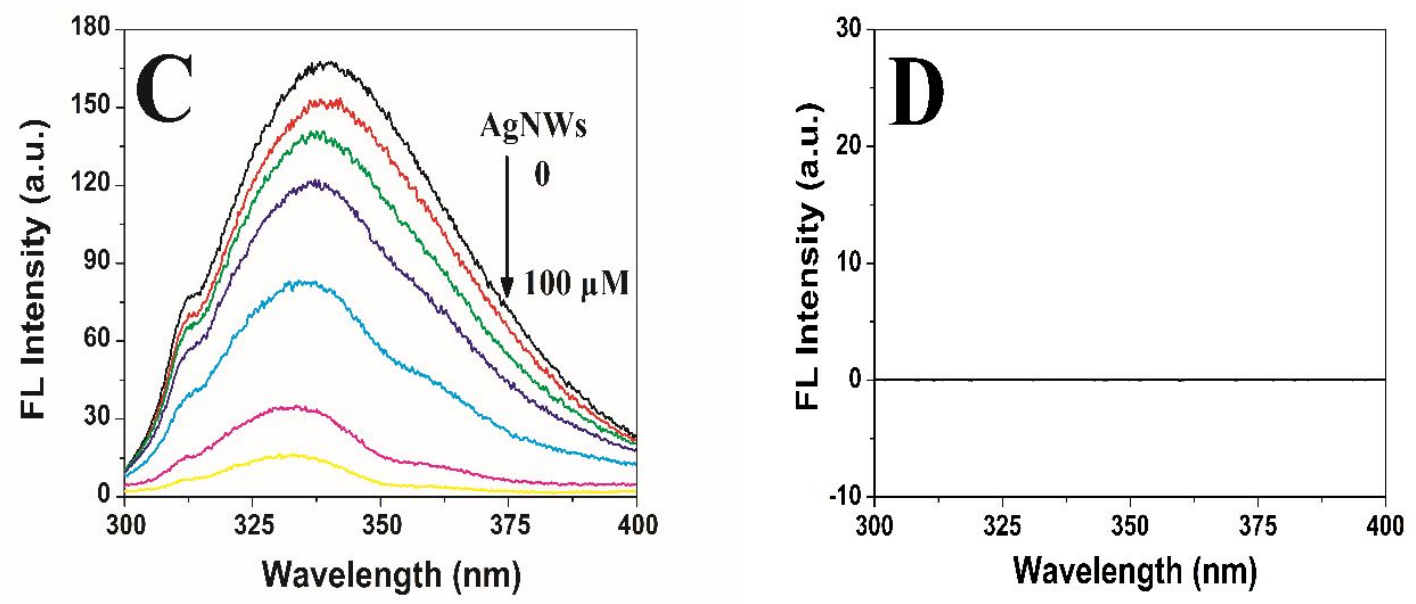

97 Figure S2 Fluorescence emission spectra of different proteins in the presence of AgNWs at the

98 concentration of $0,1,5,10,20,50,100 \mu \mathrm{M}$. (A) OVA. (B) BSA. (C) LYZ. And fluorescence

99 emission spectra of pure AgNWs at $100 \mu \mathrm{M}$ (D).

100 


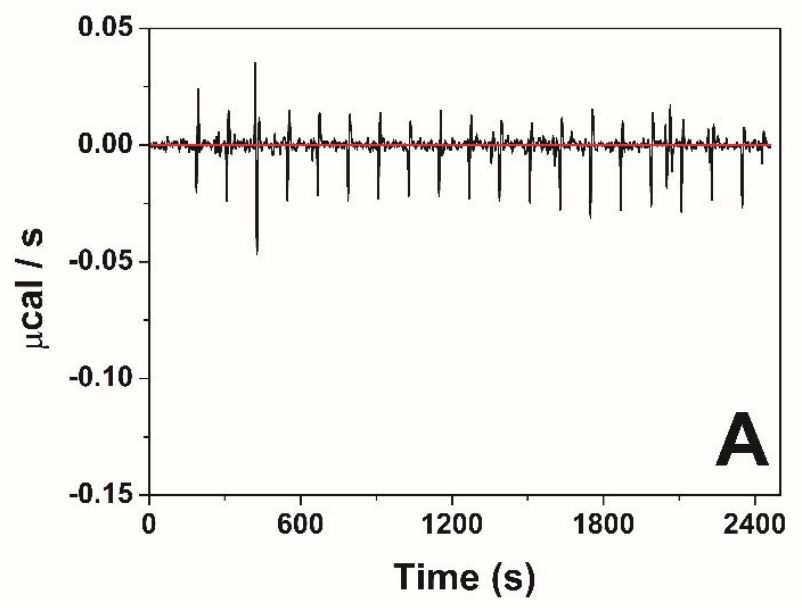

102
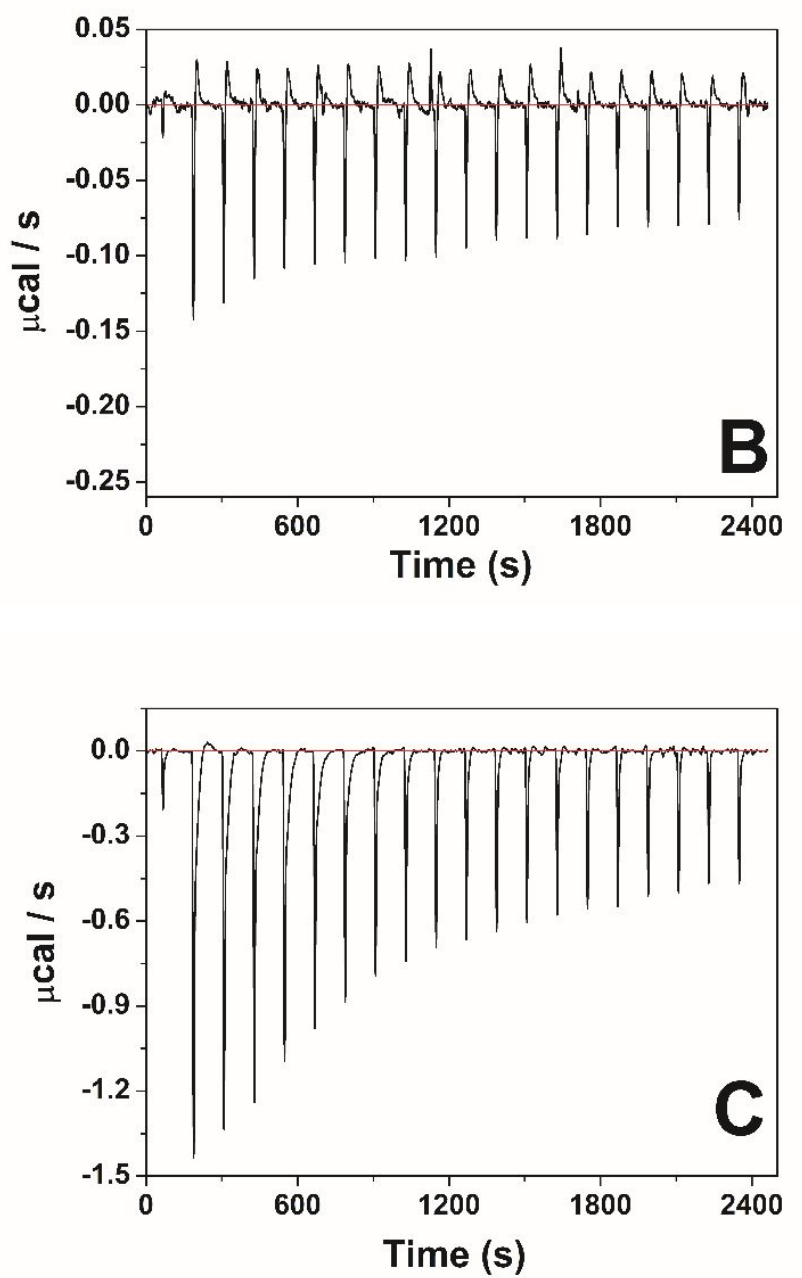

104 Figure S3. The raw data from ITC process. (A) OVA solution titrated into AgNWs solution. (B)

105 BSA solution titrated into AgNWs solution. (C) LYZ solution titrated into AgNWs solution. 106 


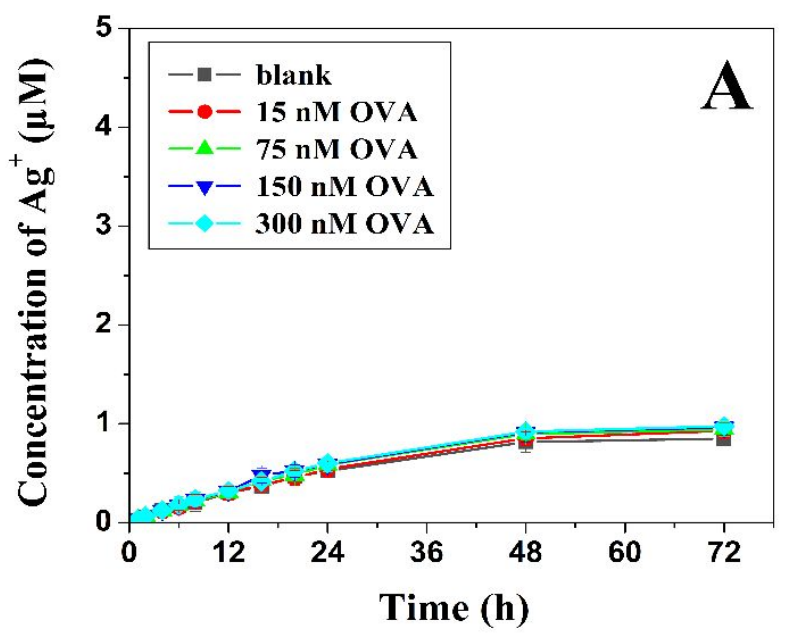

107

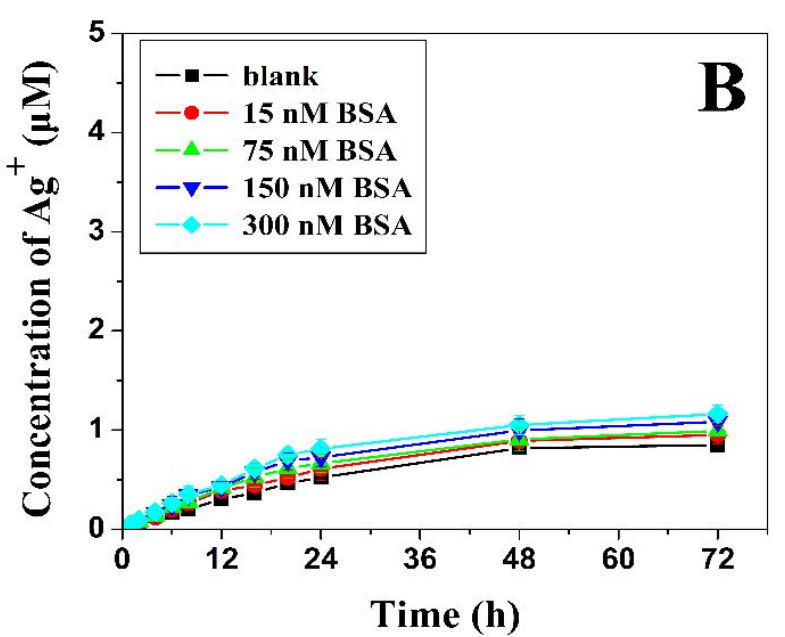

108

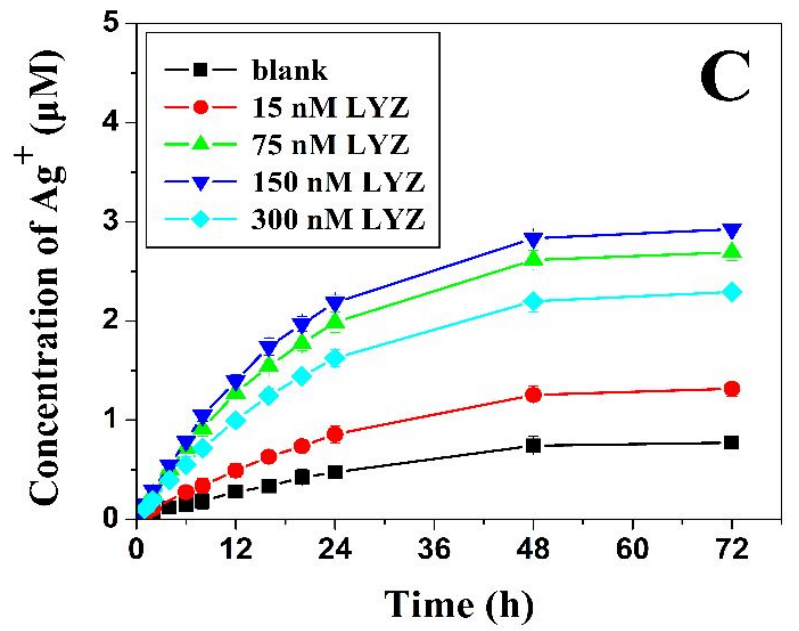

110 Figure S4 AgNWs dissolution kinetics in the absence and presence of (A) OVA, (B) BSA, (C)

111 LYZ at different concentrations. Data points represent the average of three independent replicates. 

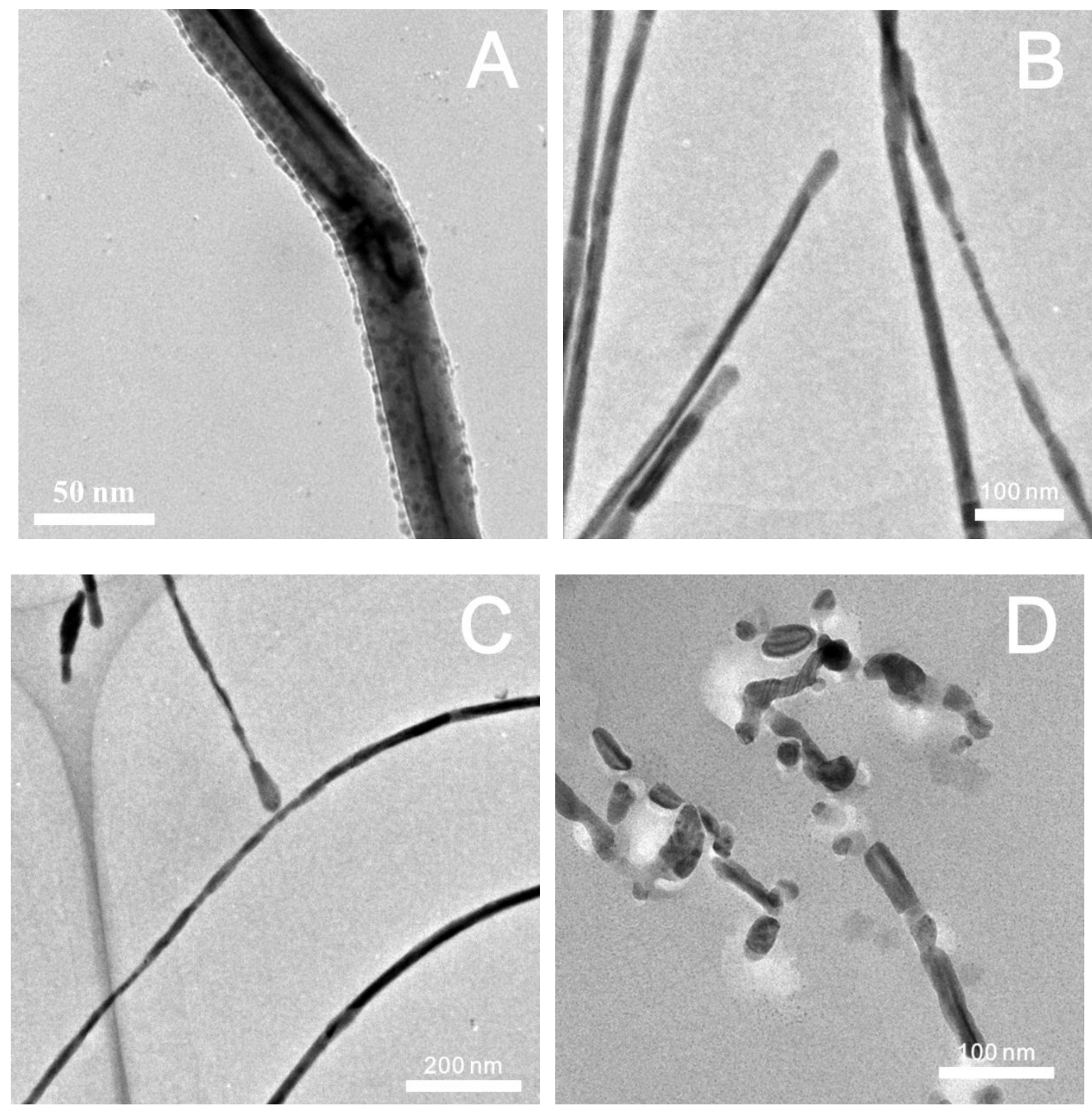

114 Figure S5 TEM images of AgNWs dispersed in different reaction solutions under sunlight 115 irradiation for $6 \mathrm{~h}$. (A) In water. The scale bar represents $50 \mathrm{~nm}$. (B) In $300 \mathrm{nM}$ of OVA solutions.

116 The scale bar represents $100 \mathrm{~nm}$. (C) In $300 \mathrm{nM}$ of BSA solutions. The scale bar represents 200 117 nm. (D) In $300 \mathrm{nM}$ of LYZ solutions. The scale bar represents $100 \mathrm{~nm}$. 

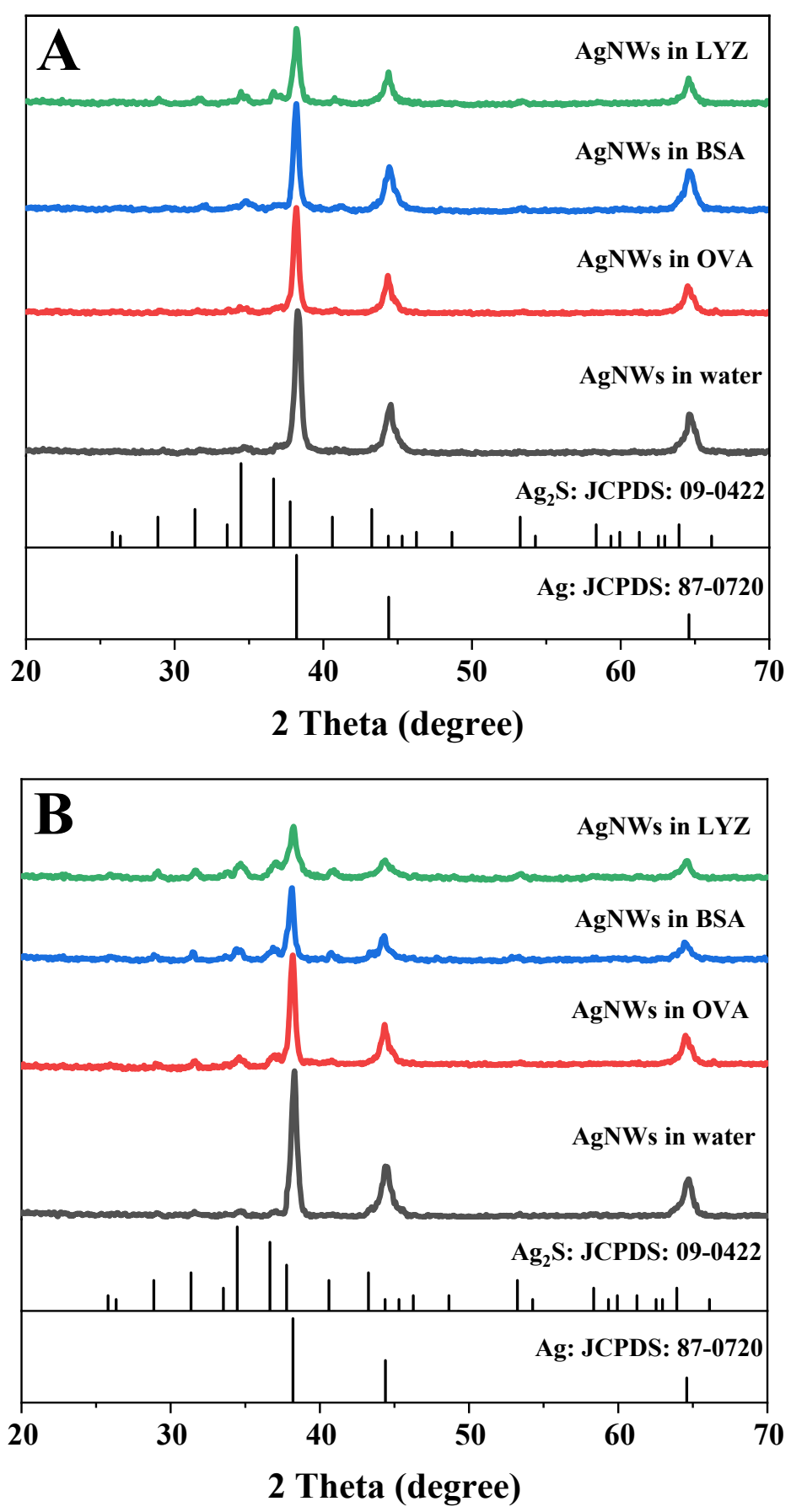

121 Figure S6 XRD patterns of AgNWs sulfidation products after reacting for (A) $1 \mathrm{~h}$ and (B) $8 \mathrm{~h}$ in 122 water and three types of proteins at $75 \mathrm{nM}$. 


\section{References}

125 1. Sun, Y.; Xia, Y. Large-scale synthesis of uniform silver nanowires through a soft, self- seeding, polyol 126 process. Adv. Mater. 2002, 14 (11), 833-837.

127 2. J. Mariam, P. M. Dongre and D. C. Kothari, Study of interaction of silver nanoparticles with bovine serum albumin using fluorescence spectroscopy, Journal of Fluorescence, 2011, 21, 2193.

129 3. S. Li, J. J. Mulloor, L. Wang, Y. Ji, C. J. Mulloor, M. Micic, J. Orbulescu and R. M. Leblanc, Strong and selective adsorption of lysozyme on graphene oxide, ACS Applied Materials \& Interfaces, 2014, 6 , 5704-5712.

132 4. S. Jiang, H.-Z. Liu, W.-L. Cai, A.-m. Bai, Y. Ouyang and Y.-J. Hu, Quasi-spherical silver nanoparticles 133 with high dispersity and uniform sizes: preparation, characterization and bioactivity in their interaction 134 with bovine serum albumin, Luminescence, 2016, 31, 1146-1151.

135 5. Y.-P. Wang, Y.-1. Wei and C. Dong, Study on the interaction of 3,3-bis(4-hydroxy-1-naphthyl)phthalide with bovine serum albumin by fluorescence spectroscopy, Journal of Photochemistry and Photobiology A: Chemistry, 2006, 177, 6-11.

138 6. Z. Nan, C. Hao, X. Ye, Y. Feng and R. Sun, Interaction of graphene oxide with bovine serum albumin: A fluorescence quenching study, Spectrochimica Acta Part A-Molecular And Biomolecular 140 Spectroscopy, 2019, 210, 348-354. 